\title{
Does harvest residue management influence biomass and nutrient accumulation in understory vegetation of Eucalyptus globulus Labill. plantations in a Mediterranean environment?
}

\author{
M. Carneiro, V. Serrão, A. Fabião*, M. Madeira, I. Balsemão, L. Hilário \\ Instituto Superior de Agronomia - Universidade Técnica de Lisboa, Tapada da Ajuda, P-1349-017 Lisboa, Portugal
}

A R T I C L E I N F O

\section{Article history:}

Received 30 May 2008

Received in revised form 11 September 2008 Accepted 17 September 2008

\section{Keywords:}

Eucalyptus plantations

Ground vegetation

NAPP

Nutrients

Slash

\begin{abstract}
A B S T R A C T
The effect of harvest residue management options on biomass and nutrient accumulation in understory vegetation, as well as the contribution of understory to nutrient cycling, were assessed during the early rotation stage of a Eucalyptus globulus Labill. plantation in Central Portugal. The effects of residue management options on early tree growth were also evaluated. Treatments established at the time of plantation and replicated four times in a simple completely randomised design included removal of harvest residues (R), incorporation of residues into the soil by harrowing (I) and maintenance of residues on the soil surface (S). Understory biomass was sampled in the spring between 2002 and 2006, and every 2 months between March 2006 and March 2007. The latter samples were stratified into biomass, standing dead mass and litter for net above ground primary production (NAPP) assessment. Samples were oven dried, weighed and analysed for nutrient contents. Results showed that understory standing biomass strongly increased from the first to the third year and that quantities of nutrients accumulated in ground vegetation followed similar patterns between the three treatments. Nutrient accumulation in ground vegetation was greater than in tree biomass until at least the second spring after plantation. Bimonthly sampling revealed treatment $\mathrm{R}$ to have the largest amounts of standing biomass, standing dead mass, litter and nutrient immobilisation, while treatment $S$ exhibited the lowest values. NAPP (4th-5th year) was 639,511 and $362 \mathrm{~g} \mathrm{~m}^{-2}$ year $^{-1}$, respectively in $\mathrm{R}, \mathrm{I}$ and $\mathrm{S}$, corresponding the standing biomass increase to 277,183 and $143 \mathrm{~g} \mathrm{~m}^{-2}$ year $^{-1}$. These values are comparable to those observed for litter fall in similar stands (age and tree density) in the same area. The contribution of ground vegetation to nutrient accumulation in the system was unaffected by harvest residue management methods, but further research is necessary in order to establish whether slash management options influence long term tree growth and vegetation dynamics.
\end{abstract}

(c) 2008 Elsevier B.V. All rights reserved.

\section{Introduction}

In most forest ecosystems, the vast majority of plant species occurs in the understory (Halpern and Spies, 1995). The presence of herbs and shrubs is important for nutrient cycling and conservation (Emmett et al., 1991; Bauhus et al., 2001), soil organic C content, soil aggregation stability (Tisdall and Oades, 1982) and seedling protection from wind and frost (Smith et al., 1997, p. 209). The forest understory is an important component of forest aesthetics, increasing their environmental value and the scenic quality of the landscape (Crowe, 1966, 1978; Forestry Commission, 1994).

In intensive short rotation forest plantations, competition for water and nutrients between understory and tree seedlings is

\footnotetext{
* Corresponding author. Tel.: +351 2136534 88; fax: +351 213645000 .

E-mail address: afabiao@isa.utl.pt (A. Fabião).
}

undesirable at the onset of stand development, particularly during summer drought conditions (Nyland, 1996, pp. 116-118 and 158; Smith et al., 1997, p. 208), such as those that prevail in Mediterranean environments. However, the structural and functional properties of understory vegetation during early stand development can be beneficial as developing herbs and shrubs contribute to the total annual amount of litter added to stands (Yarie, 1980) and may affect the soil nutrient status (Emmett et al., 1991; Fahey et al., 1991) through nutrient uptake and decreasing water percolation in the soil profile (Gholz et al., 1985; Palviainen, 2005). However, understory vegetation has often been overlooked in biomass, mineral mass and primary production studies of intensive forest plantations (Tremblay and Larocque, 2001; Archer, 2003).

Short rotation Eucalyptus globulus Labill. plantations expanded in the Iberian Peninsula during the last decades. These plantations are usually harvested by clear cutting; harvest residues are often removed and the soil gets disturbed during timber extraction. 
Management of large amounts of harvest residues in these plantations can affect understory vegetation (Jones et al., 1999). For example, harvest residue removal can adversely affect site fertility (Nyland et al., 1979; Abbott and Crossley, 1982; Burger and Prichett, 1984; Smith et al., 1997, pp. 199-201; Mathers et al., 2003) as well as the regeneration and survival rates of native species present in the understory (Smith et al., 1997, pp. 199-201; Bauhus et al., 2001) which, in extreme situations, can threaten future tree development (Emmett et al., 1991). The increase in light following harvest residue removal can stimulate the regeneration of shade intolerant colonisers such as grasses (e.g. Fahey et al., 1991; Olsson and Staaf, 1995) although increased solation has been observed to exert no significant effect on grass and sedge development in stands of Norway spruce (Bergquist et al., 1999). Re-establishment of understory vegetation is hindered mostly by logging operations and ground cover of harvest residues (Fahey et al., 1991; Olsson and Staaf, 1995; Lister, 1999).

Appropriate management of harvest residues and nutrient cycling is necessary for enhancing site productivity in short rotation eucalyptus plantations (Adams and Attiwill, 1986; Shammas et al., 2003), but the presence and diversity of understory vegetation are also important contributors to the sustainability of fast growing forest tree plantations (Carnus et al., 2003). Harvest residue management systems (removal or maintenance) are a source of strong current debate, not only because of soil quality considerations, but also the use of residues for bioenergy purposes (Cowie et al., 2006; Stupak et al., 2007), an initiative actively encouraged by Portuguese Forestry Commission (2006, http:// www.afn.min-agricultura.pt/portal/politica-e-planeamento-florestal/enf/estrategia-nacional-para-as-florestas/).

Similar to other intensive plantation studies (Tremblay and Larocque, 2001; Archer, 2003), studies on understory vegetation in eucalyptus plantations in Mediterranean conditions have focused on species richness and biodiversity (Fabião et al., 2002; Carneiro et al., 2007, 2008). A greater understanding of understory productivity and nutrient dynamics is essential in order to contribute to the development of improved establishment and management strategies, taking into account timber production, environmental sustainability and understory biodiversity conservation (Hartley, 2002; Carnus et al., 2003). The aims of this study, carried out in a representative area of intensive eucalyptus plantations in Central Portugal were (1) to assess the effects of different harvest residue management options on tree growth, biomass and growth dynamics of understory vegetation on a $E$. globulus plantation, and (2) to evaluate whether ground vegetation contributes to nutrient accumulation in the early rotation stage (before stand canopy closure and stem exclusion phase) of eucalyptus plantations.

\section{Methods and materials}

\subsection{Site characteristics}

The experimental trial site was established in a replanted area of E. globulus, following harvesting (in autumn 2001) of the previous 34 years old coppice. The site, at Quinta do Furadouro $\left(39^{\circ} 20^{\prime} \mathrm{N}, 9^{\circ} 13^{\prime} \mathrm{W}, 30 \mathrm{~m}\right.$ a.s.l.), in West Central Portugal, has a Mediterranean climate, with an oceanic influence. Meteorological data from the Caldas da Raínha station approximately $12 \mathrm{~km}$ from the site, $70 \mathrm{~m}$ a.s.l. show a mean annual temperature of $15.2^{\circ} \mathrm{C}$, ranging from $19.8^{\circ} \mathrm{C}$ in August to $10.4{ }^{\circ} \mathrm{C}$ in January with occasional sub zero temperature during the winter. Mean annual rainfall is $607 \mathrm{~mm}$, with less than 10\% of this amount occurring between May and September. High atmospheric humidity occurs in summer mornings resulting in frequent summer fogs that attenuate the effects of summer drought (Reis and Gonçalves, 1981).

The landscape is flat to gently undulating. Soils at the site comprise Haplic Cambisols (Dystric) and Haplic Regosols (Dystric) (WRB, 2006), developed on Cretacic ("Grés de Torres Vedras"; Zbyzewski et al., 1966) and Jurassic Sandstone with fossil remains of plants and dinosaurs (Zbyszewski and Almeida, 1960). These soils have a sandy-loam to loam texture, with low $\mathrm{pH}\left(\mathrm{H}_{2} \mathrm{O}\right)$ values $(<5.3)$, low organic $C$ contents (10.9-24.3 $\left.\mathrm{g} \mathrm{kg}^{-1}\right)$ and extremely low extractable $\mathrm{P}$ contents ( $<5 \mathrm{mg} \mathrm{kg}^{-1}$; Jones et al., 1999).

The potential natural vegetation is of the vegetation series Asparago aphylli-Querceto suberis sigmetum (Costa et al., 2002), dominated by Quercus faginea subsp. broteroi (Cout.) A. Camus and Quercus suber L. (Cabral and Telles, 1960). Pinus pinaster Aiton, Pinus pinea L., Phillyrea latifolia L., Quercus coccifera L., and Castanea sativa Mill. are some of the tree and shrub species which also occur in the area.

\subsection{Experimental design}

Starting in March 2002, seedlings were planted at $3 \times 3 \mathrm{~m}^{2}$ spacing (ca. 1111 seedlings ha ${ }^{-1}$ ). A NPK commercial fertiliser (ratio 36\%:10\%:10\% NPK) was applied close to $(20-25 \mathrm{~cm}$ ) each tree seedling ( $100 \mathrm{~g} /$ seedling). Stump sprouting of the previous plantation was controlled by glyphosate application.

The experimental design consisted of three treatments replicated in four different plots: $(R)$ removal of harvest residues from the site, $(S)$ maintenance of harvest residues on the soil surface and (I) incorporation of harvest residues into the soil by harrowing up to $20 \mathrm{~cm}$ depth. Each treatment plot area was $729 \mathrm{~m}^{2}$, with a core of 25 measurable trees surrounded by two buffer rows of trees on all four sides.

\subsection{Measurements and sampling}

Tree height $(h)$ was measured in October 2002, September 2003, August 2004, September 2005 and August 2006 (7, 18, 29, 42 and 53 months after planting, respectively) with a measuring rod placed at the foot of the tree. Diameter was measured at breast height (DBH) with a calliper (average of two cross measurements per tree) in August 2004, September 2005 and August 2006 (29, 42 and 53 months after planting respectively).

Every spring from 2002 to 2006 , a wooden frame $\left(0.5 \times 0.5 \mathrm{~m}^{2}\right)$ was randomly applied four times in each treatment plot in order to sample above ground standing biomass. In March, May, July, September and November 2006, and January and March 2007, a further three samples were taken from each plot for measurements of net above ground primary production (NAPP), giving a total of 36 samples ( 4 plots $\times 3$ treatments $\times 3$ replicates) in each sampling occasion.

In both annual and bimonthly samples, all understory plants inside the frame were harvested by clipping vegetation close to the ground (Kent and Coker, 1992), oven dried at $80-85^{\circ} \mathrm{C}$ to a constant dry weight, weighed and analysed for nutrient content. In the annual samples, understory standing mass was treated as a whole, i.e. no distinction was made between biomass and standing dead mass (the latter is usually scarce in spring sampling). In the bimonthly samples, vegetation mass was separated into living plant parts and standing dead plant material. Understory litter (dead plant parts separated from plant bodies and laying over the soil) was also collected, discarding tree litter, easily recognised by the peculiar structure of eucalyptus decomposing leaves, twigs and bark fragments. From hereon these understory plant fractions will be referred to as standing biomass, standing dead mass and litter, respectively. 


\subsection{Laboratory procedures}

Vegetation samples collected from the frame in each treatment plot were combined and ground for nutrient analysis. $\mathrm{N}$ concentration was determined by Kjeldahl digestion analysis (Digestion System 40, Kjeltec Auto 1030 Analyser) (Póvoas and Barral, 1992). Solubilisation of residue elements (P, Ca, K and Mg) was obtained by digestion (CEM Microwave Digestion System Model MDS-81 D) of $0.5 \mathrm{~g}$ of material in $10 \mathrm{~mL} \mathrm{HNO}_{3}$ at 65\% (LDV tubes) and in $2 \mathrm{~mL} \mathrm{H}_{2} \mathrm{O}_{2}$ at $30 \%$. The resulting solution was evaporated in "Fourneau" glasses, and the respective residue solubilised by the addition of $10 \mathrm{~mL} \mathrm{HCl} 3 \mathrm{M}$. Ca, K and $\mathrm{Mg}$ were determined by atomic absorption spectrometry (AAS). P was quantified by the Murphy \& Riley ascorbic acid method (Póvoas and Barral, 1992) and determined by spectrophotometry (Pye Unicam SP8-400 UV/VIS).

\subsection{Assessment of net aboveground primary production (NAPP) and nutrient dynamics}

NAPP was evaluated at 2-month intervals using the decision matrix method (Aber and Melillo, 1982; Petterson, 1987) in order to assess increases in biomass, standing dead mass and litter. Litter disappearance (LD) was calculated using the formula $\mathrm{LD}=(\mathrm{A}-$ $\left.L_{i}+L\right)-A L_{e}$, where $A L_{i}$ is the initial amount of litter, $L$ is the litter estimated increase in the 2-month period and $\mathrm{AL}_{\mathrm{e}}$ the amount of litter at the end of the 2-month period. Nutrient balance was evaluated using similar methodology. Annual estimates were calculated as the sum of all sampling intervals over the year.

\subsection{Data analyses}

For each treatment, annual values of spring standing biomass, quantities of accumulated nutrients (N, P, K, Ca and $\mathrm{Mg}$ ) and bimonthly values of standing biomass, standing dead mass, litter and nutrients between the fifth and sixth spring, were converted to unit area basis values and statistically compared using the SPSS Statistical Program for Windows, version 11.5 (๑SPSS Inc.). Normality of data distribution and homogeneity of variance were confirmed by Kolmogorov-Smirnov test and Levene test, respectively. Where homogeneity of variance was confirmed, comparisons were made using the parametric one-way ANOVA and the multiple comparison Tukey test, considering treatments as independent variables and the estimated parameters as dependent variables. When variance was not equal, even following data transformation, averages were compared using the non parametric Dunnett's T3 test. The significance level of $p<0.05$ was used in all data statistical analysis.

\section{Results}

\subsection{Tree growth}

Trees in treatment I grew faster than in treatments $\mathrm{S}$ and $\mathrm{R}$ (Table 1 ) over the experimental period. Average tree height 53 months after planting was $10.2,8.8$ and $8.7 \mathrm{~m}$, respectively in treatments I, R and S. Mean diameter at breast height reached $8.0 \mathrm{~cm}$ for treatment $\mathrm{I}$ and $6.6 \mathrm{~cm}$ in treatments $\mathrm{R}$ and $\mathrm{S}$. Statistically significant differences between treatments were only observed in 2003, 18 months after planting, when treatment I had significantly greater height than $\mathrm{S}$. However, the difference in tree height between these two treatments decreased (when compared to mean height values) until the end of the study. Tree DBH values were of the same magnitude during the measurement period, although treatment I consistently ranked the greatest DBH.
Table 1

Tree height and diameter at breast height (mean \pm standard error) in treatment plots during the study period ( $n=4 ; 25$ trees per plot). Values in the same line marked with different letters differ significantly between treatments $(p<0.05$, ANOVA procedure and Tukey test). Treatments are: $\mathrm{R}$ - removal of harvest residues from the site; $\mathrm{S}$ maintenance of harvest residues on soil surface; I - incorporation of harvest residues in soil by harrowing up to $20 \mathrm{~cm}$.

\begin{tabular}{llll}
\hline Date & \multicolumn{3}{l}{ Treatments } \\
\cline { 2 - 4 } & $\mathrm{R}$ & $\mathrm{I}$ & $\mathrm{S}$ \\
\hline Tree height (m) & & & \\
October 2002 (7 map) & $1.3 \pm 0.1$ & $1.7 \pm 0.1$ & $1.3 \pm 0.1$ \\
September 2003 (18 map) & $3.1 \pm 0.2 \mathrm{ab}$ & $4.3 \pm 0.4 \mathrm{a}$ & $3.0 \pm 0.2 \mathrm{~b}$ \\
August 2004 (29 map) & $4.9 \pm 0.4$ & $6.3 \pm 0.6$ & $4.8 \pm 0.4$ \\
September 2005 (42 map) & $6.9 \pm 0.4$ & $8.4 \pm 0.8$ & $7.0 \pm 0.6$ \\
August 2006 (53 map) & $8.7 \pm 1.0$ & $10.2 \pm 0.8$ & $8.8 \pm 0.8$ \\
Diameter at breast height (cm) & & & \\
August 2004 (29 map) & $3.5 \pm 0.4$ & $4.5 \pm 0.4$ & $3.7 \pm 0.3$ \\
September 2005 (42 map) & $5.1 \pm 0.6$ & $6.2 \pm 0.7$ & $5.1 \pm 0.6$ \\
August 2006 (53 map) & $6.6 \pm 0.9$ & $8.0 \pm 0.8$ & $6.6 \pm 0.6$ \\
\hline
\end{tabular}

map - months after plantation.

\subsection{Annual biomass and nutrient amounts}

In the first 4 years of the rotation, understory vegetation biomass consistently followed the same trend for all treatments (Table 2), with statistically significant differences between I and $\mathrm{R}$ or $\mathrm{S}$ occurring only during the first growing season. Understory biomass strongly increased from the first (33.3-169.9 $\mathrm{g} \mathrm{m}^{-2}$ ) to the second (320.4-352.1 $\mathrm{g} \mathrm{m}^{-2}$ ) growing season, with maximum values observed in the third growing season $\left(481.1 \mathrm{~g} \mathrm{~m}^{-2}\right.$ in $\mathrm{I}$, $457.2 \mathrm{~g} \mathrm{~m}^{-2}$ in $\mathrm{R}$, and $359.3 \mathrm{~g} \mathrm{~m}^{-2}$ in S), 27 months after planting. Understory biomass values were of the same magnitude in all treatments at the end of the study period.

Ground vegetation accumulated nutrient levels followed approximately the same pattern observed for biomass over the study period. $\mathrm{N}$ and $\mathrm{K}$ were accumulated in greatest quantities, with the highest values occurring in 2004 in treatment R (4.28 and $4.38 \mathrm{~g} \mathrm{~m}^{-2}$ of $\mathrm{N}$ and $\mathrm{K}$, respectively) and treatment I (5.16 and $5.55 \mathrm{~g} \mathrm{~m}^{-2}$ of $\mathrm{N}$ and $\mathrm{K}$, respectively, Table 3 ). In contrast, $\mathrm{P}$ and $\mathrm{Mg}$ were the mineral nutrients least accumulated by understory vegetation. Magnesium attained the highest values during the second growing season in 2003 in treatments I and S (0.52 and $0.71 \mathrm{~g} \mathrm{~m}^{-2}$ respectively), while P maximum occurred in 2004 in treatments $R$ and $\mathrm{I}$ ( 0.50 and $0.53 \mathrm{~g} \mathrm{~m}^{-2}$, respectively). Differences in accumulated nutrients between treatments were not statistically significant at any time.

\subsection{Bimonthly mass and nutrient variation}

Treatment $\mathrm{R}$ had the largest amount (bimonthly sampling) of standing biomass, standing dead mass and litter of understory vegetation throughout 1 year (Fig. 1), between the fifth and sixth growing seasons (March 2006 to March 2007). Mean total mass

Table 2

Standing understory biomass $\left(\mathrm{g} \mathrm{m}^{-2}\right)$ measured in spring during the study period (mean \pm standard error, $n=4$ ). Values in the same row followed by different letters differ significantly between treatments $(p<0.05$, ANOVA procedure and Tukey and Dunnett's T3 tests). Treatments are given in Table 1.

\begin{tabular}{llcl}
\hline Year & \multicolumn{3}{l}{ Treatments } \\
\cline { 2 - 4 } & $\mathrm{R}$ & $\mathrm{I}$ & $\mathrm{S}$ \\
\hline 2002 & $166.71 \pm 53.89 \mathrm{a}$ & $33.25 \pm 7.41 \mathrm{~b}$ & $169.86 \pm 36.38 \mathrm{a}$ \\
2003 & $352.05 \pm 72.18$ & $320.38 \pm 58.99$ & $343.67 \pm 22.22$ \\
2004 & $457.20 \pm 81.72$ & $481.05 \pm 54.58$ & $359.28 \pm 59.30$ \\
2005 & $264.95 \pm 10.61$ & $416.26 \pm 79.50$ & $356.39 \pm 76.52$ \\
2006 & $248.83 \pm 34.60$ & $177.13 \pm 25.95$ & $170.04 \pm 11.87$ \\
\hline
\end{tabular}


Table 3

Nutrient accumulation $\left(\mathrm{g} \mathrm{m}^{-2}\right)$ in understory vegetation in treatment plots during the study period (mean \pm standard error, $n=4$ ). Differences between treatments were not statistically significant ( $p>0.05$, ANOVA procedure). Treatments are given in Table 1.

\begin{tabular}{clllll}
\hline Treatment & 2002 & 2003 & 2004 & 2005 & 2006 \\
\hline $\begin{array}{c}\text { Nutrient accumulation }\left(\mathrm{g} \mathrm{m}^{-2}\right) \\
\mathrm{N}\end{array}$ & & & & \\
$\mathrm{R}$ & $1.98 \pm 0.53$ & $2.99 \pm 0.56$ & $4.28 \pm 0.90$ & $2.56 \pm 0.14$ & $2.56 \pm 0.39$ \\
$\mathrm{I}$ & $0.74 \pm 0.25$ & $4.21 \pm 1.14$ & $5.16 \pm 0.94$ & $4.19 \pm 0.67$ & $1.61 \pm 0.30$ \\
$\mathrm{~S}$ & $1.88 \pm 0.39$ & $2.92 \pm 0.13$ & $2.91 \pm 0.53$ & $3.85 \pm 1.28$ & $1.67 \pm 0.08$ \\
$\mathrm{P}$ & & & & & \\
$\mathrm{R}$ & $0.28 \pm 0.10$ & $0.41 \pm 0.09$ & $0.50 \pm 0.11$ & $0.31 \pm 0.04$ & $0.30 \pm 0.05$ \\
$\mathrm{I}$ & $0.08 \pm 0.03$ & $0.46 \pm 0.14$ & $0.53 \pm 0.13$ & $0.41 \pm 0.09$ & $0.16 \pm 0.03$ \\
$\mathrm{~S}$ & $0.25 \pm 0.07$ & $0.36 \pm 0.05$ & $0.34 \pm 0.06$ & $0.35 \pm 0.07$ & $0.18 \pm 0.02$ \\
$\mathrm{Ca}$ & & & & & \\
$\mathrm{R}$ & $0.87 \pm 0.16$ & $2.04 \pm 0.55$ & $1.97 \pm 0.38$ & $1.38 \pm 0.26$ & $1.63 \pm 0.42$ \\
$\mathrm{I}$ & $0.17 \pm 0.06$ & $1.89 \pm 0.38$ & $1.72 \pm 0.22$ & $1.57 \pm 0.25$ & $0.69 \pm 0.19$ \\
$\mathrm{~S}$ & $1.63 \pm 0.76$ & $2.00 \pm 0.29$ & $1.60 \pm 0.18$ & $1.38 \pm 0.16$ & $0.90 \pm 0.09$ \\
$\mathrm{~K}$ & & & & & \\
$\mathrm{R}$ & $2.93 \pm 0.51$ & $3.74 \pm 0.83$ & $4.38 \pm 0.88$ & $2.60 \pm 0.12$ & $2.66 \pm 0.32$ \\
$\mathrm{I}$ & $0.85 \pm 0.33$ & $4.95 \pm 1.62$ & $5.55 \pm 1.36$ & $3.48 \pm 0.44$ & $1.47 \pm 0.27$ \\
$\mathrm{~S}$ & $5.57 \pm 2.71$ & $3.55 \pm 0.12$ & $3.05 \pm 0.44$ & $3.24 \pm 0.56$ & $1.86 \pm 0.15$ \\
$\mathrm{Mg}$ & & & & & \\
$\mathrm{R}$ & $0.23 \pm 0.04$ & $0.46 \pm 0.10$ & $0.48 \pm 0.07$ & $0.39 \pm 0.04$ & $0.44 \pm 0.05$ \\
$\mathrm{I}$ & $0.06 \pm 0.02$ & $0.52 \pm 0.13$ & $0.51 \pm 0.10$ & $0.46 \pm 0.05$ & $0.22 \pm 0.07$ \\
$\mathrm{~S}$ & $0.46 \pm 0.20$ & $0.71 \pm 0.22$ & $0.45 \pm 0.03$ & $0.47 \pm 0.10$ & $0.28 \pm 0.03$ \\
\hline & & & & &
\end{tabular}

(including standing biomass, standing dead and litter) increased in the first 6 months (March-September) in treatment R, reaching $405 \mathrm{~g} \mathrm{~m}^{-2}$ in September, and decreasing to $294 \mathrm{~g} \mathrm{~m}^{-2}$ the following March. Treatment S usually had the lowest mean total mass, except at the beginning and end of the experiment, when treatment I had the lowest values (151 and $123 \mathrm{~g} \mathrm{~m}^{-2}$, in March 2006 and March 2007, respectively).

Maximum values of standing dead understory vegetation occurred in July and September in all treatments, coinciding with summer drought and the end of the annual plant biological cycle. No statistically significant differences were observed between treatments either in standing biomass or standing dead amounts. Only in July, treatment $\mathrm{R}$ had significantly higher amounts of litter $\left(140 \mathrm{~g} \mathrm{~m}^{-2}\right.$ ), than treatments I and S (82 and $90 \mathrm{~g} \mathrm{~m}^{-2}$, respectively), and in January the amount of litter was significantly greater in $\mathrm{R}\left(67 \mathrm{~g} \mathrm{~m}^{-2}\right)$ than in $\mathrm{S}\left(29 \mathrm{~g} \mathrm{~m}^{-2}\right)$.

Treatment $R$ consistently accumulated the most nutrients over the 1-year study period (Table 4). Statistically significant differences between treatments only occurred in the amounts accumulated in litter in January ( N, P, Ca and Mg) and in July (Ca and $\mathrm{Mg}$ ). In general, $\mathrm{S}$ treatment had the lowest values of $\mathrm{N}, \mathrm{P}$ and $\mathrm{K}$, and I treatment of Ca and $\mathrm{Mg}$ (except in May, when S treatment had minimum values).

Nutrient accumulation in understory biomass was highest in spring (March-May), whereas the maximum amounts in standing dead and litter occurred in summer (July-September).

\subsection{NAPP and nutrient dynamics}

The annual increase in standing biomass, standing dead mass and litter between March 2006 and March 2007 is shown in Fig. 2. Treatment $\mathrm{R}$ had the highest values for all components, as well as for litter disappearance (Fig. 3). The annual increment in biomass was 278,183 and $143 \mathrm{~g} \mathrm{~m}^{-2}$ year $^{-1}$, in treatments $\mathrm{R}, \mathrm{I}$ and $\mathrm{S}$, respectively. Differences in standing dead mass and litter annual increases were less pronounced, but the treatments ranked in the same order: $181>180>102 \mathrm{~g} \mathrm{~m}^{-2}$ year $^{-1}$ for standing dead and $181>148>117 \mathrm{~g} \mathrm{~m}^{-2}$ year $^{-1}$ for litter increase. Taking into account the annual increases of biomass, standing dead and litter NAPP values were 639, 511 and $362 \mathrm{~g} \mathrm{~m}^{-2}$ year $^{-1}$, respectively in treatments R, I and S. Litter disappearance values were of similar magnitude to biomass increment, with treatment $\mathrm{R}$ reaching the highest value ( $254 \mathrm{~g} \mathrm{~m}^{-2}$ year $^{-1}$ ), followed by treatments $\mathrm{S}$ and I (174 and $173 \mathrm{~g} \mathrm{~m}^{-2}$ year $^{-1}$, respectively). Fig. 3 shows that litter disappearance occurred mainly in spring and autumn and was negligible in winter and summer.

Nutrients accumulated through biomass, standing dead and litter annual increments were highest in treatment $R$ and decreased in treatments I (intermediate values) and S, following the same trend as organic mass (Fig. 4). Understory biomass increase accumulated more $\mathrm{K}\left(2.2-4.1 \mathrm{~g} \mathrm{~m}^{-2}\right.$ year $\left.^{-1}\right)$ than any other nutrient in all treatments, whereas Ca was the principal accumulated nutrient in standing dead mass and litter increases in treatment $\mathrm{R}$ ( 1.6 and $2.1 \mathrm{~g} \mathrm{~m}^{-2}$ year $^{-1}$, respectively) and treatment $\mathrm{S}$ (1.6 and $1.5 \mathrm{~g} \mathrm{~m}^{-2}$ year $^{-1}$, respectively). The highest values of $\mathrm{N}$ accumulation occurred in standing dead and litter annual increases of treatment I (1.6 and $1.2 \mathrm{~g} \mathrm{~m}^{-2}$ year $^{-1}$, respectively).

\section{Discussion}

There was no significant difference in annual understory biomass levels between the harvest residue management strategies during the study period except for treatment I in the first growing season, a few months after planting. These results are similar to those reported by Fabião et al. (2002) for newly planted and coppiced stands in a neighbouring area, between the second and sixth year, where treatment $\mathrm{R}$ comprised removal of both harvest residues and the forest litter layer. This indicates that any of the three applied management strategies will give the same

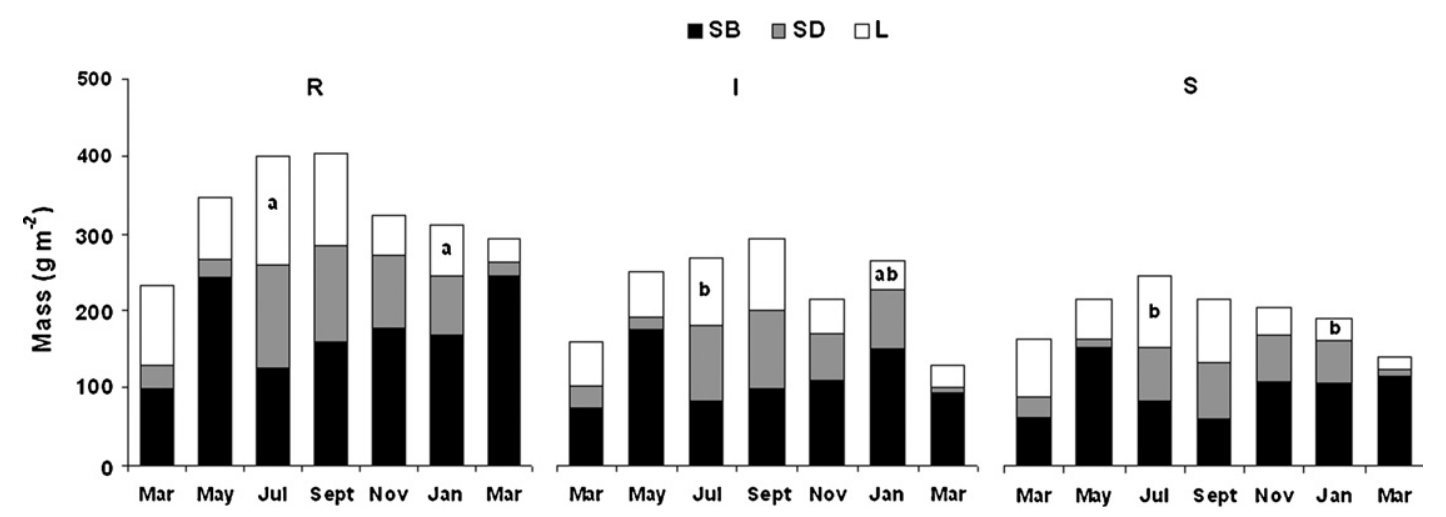

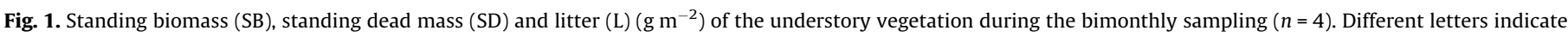

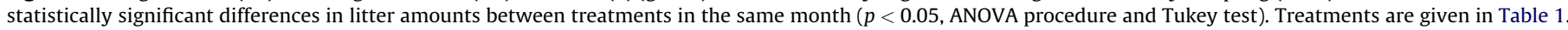


Table 4

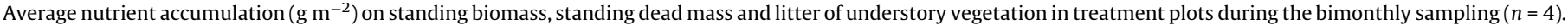

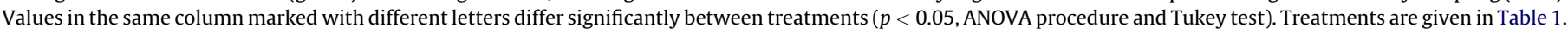

\begin{tabular}{|c|c|c|c|c|c|c|c|c|}
\hline Treatment & Mass & March & May & July & September & November & January & March \\
\hline \multicolumn{9}{|l|}{$\mathrm{N}$} \\
\hline \multirow[t]{3}{*}{$\mathrm{R}$} & Biomass & 1.15 & 2.90 & 0.98 & 1.00 & 2.00 & 2.19 & 2.69 \\
\hline & Standing dead & 0.24 & 0.18 & 0.81 & 0.77 & 0.67 & 0.59 & 0.14 \\
\hline & Litter & 1.10 & 0.72 & 1.31 & 1.32 & 0.52 & $0.88 \mathrm{a}$ & 0.35 \\
\hline \multirow[t]{3}{*}{ I } & Biomass & 1.05 & 2.14 & 0.68 & 0.82 & 1.21 & 1.82 & 1.22 \\
\hline & Standing dead & 0.21 & 0.11 & 0.76 & 0.65 & 0.30 & 0.49 & 0.05 \\
\hline & Litter & 0.51 & 0.49 & 0.68 & 0.85 & 0.36 & $0.35 \mathrm{~b}$ & 0.28 \\
\hline \multirow[t]{3}{*}{$\mathrm{S}$} & Biomass & 1.01 & 1.79 & 0.57 & 0.52 & 0.99 & 1.09 & 1.23 \\
\hline & Standing dead & 0.19 & 0.09 & 0.40 & 0.41 & 0.33 & 0.36 & 0.06 \\
\hline & Litter & 0.80 & 0.44 & 0.89 & 0.79 & 0.28 & $0.25 \mathrm{~b}$ & 0.14 \\
\hline \multicolumn{9}{|l|}{$P$} \\
\hline \multirow[t]{3}{*}{$\mathrm{R}$} & Biomass & 0.17 & 0.36 & 0.12 & 0.13 & 0.23 & 0.22 & 0.30 \\
\hline & Standing dead & 0.03 & 0.02 & 0.10 & 0.10 & 0.05 & 0.05 & 0.01 \\
\hline & Litter & 0.11 & 0.07 & 0.11 & 0.11 & 0.05 & $0.05 \mathrm{a}$ & 0.02 \\
\hline \multirow[t]{3}{*}{ I } & Biomass & 0.13 & 0.24 & 0.08 & 0.06 & 0.16 & 0.19 & 0.13 \\
\hline & Standing dead & 0.02 & 0.01 & 0.06 & 0.06 & 0.03 & 0.04 & 0.00 \\
\hline & Litter & 0.04 & 0.05 & 0.06 & 0.07 & 0.04 & $0.03 \mathrm{~b}$ & 0.02 \\
\hline \multirow[t]{3}{*}{$\mathrm{S}$} & Biomass & 0.15 & 0.22 & 0.09 & 0.07 & 0.15 & 0.11 & 0.14 \\
\hline & Standing dead & 0.02 & 0.01 & 0.05 & 0.04 & 0.04 & 0.03 & 0.01 \\
\hline & Litter & 0.06 & 0.03 & 0.06 & 0.06 & 0.02 & $0.02 \mathrm{~b}$ & 0.01 \\
\hline \multicolumn{9}{|l|}{ K } \\
\hline \multirow[t]{3}{*}{$\mathrm{R}$} & Biomass & 1.05 & 3.12 & 1.15 & 0.83 & 0.74 & 1.53 & 2.61 \\
\hline & Standing dead & 0.07 & 0.13 & 0.65 & 0.33 & 0.13 & 0.19 & 0.03 \\
\hline & Litter & 0.10 & 0.11 & 0.26 & 0.19 & 0.06 & 0.11 & 0.04 \\
\hline \multirow[t]{3}{*}{ I } & Biomass & 1.08 & 2.53 & 0.75 & 0.54 & 1.29 & 2.04 & 1.41 \\
\hline & Standing dead & 0.04 & 0.14 & 0.38 & 0.18 & 0.08 & 0.14 & 0.02 \\
\hline & Litter & 0.06 & 0.11 & 0.17 & 0.09 & 0.06 & 0.06 & 0.05 \\
\hline \multirow[t]{3}{*}{$\mathrm{S}$} & Biomass & 0.92 & 1.92 & 0.76 & 0.5 & 0.86 & 1.01 & 1.55 \\
\hline & Standing dead & 0.05 & 0.11 & 0.52 & 0.15 & 0.08 & 0.11 & 0.03 \\
\hline & Litter & 0.06 & 0.08 & 0.17 & 0.08 & 0.03 & 0.07 & 0.02 \\
\hline \multicolumn{9}{|l|}{$\mathrm{Ca}$} \\
\hline \multirow[t]{3}{*}{$\mathrm{R}$} & Biomass & 1.05 & 1.48 & 0.80 & 0.89 & 1.07 & 1.16 & 1.66 \\
\hline & Standing dead & 0.19 & 0.22 & 0.97 & 0.92 & 0.58 & 0.55 & 0.14 \\
\hline & Litter & 1.04 & 0.73 & $1.54 \mathrm{a}$ & 1.42 & 0.53 & 0.98 a & 0.48 \\
\hline \multirow[t]{3}{*}{ I } & Biomass & 0.86 & 1.13 & 0.53 & 0.39 & 0.59 & 0.83 & 0.56 \\
\hline & Standing dead & 0.15 & 0.19 & 0.63 & 0.67 & 0.29 & 0.44 & 0.06 \\
\hline & Litter & 0.53 & 0.55 & $0.84 \mathrm{~b}$ & 0.68 & 0.40 & $0.32 \mathrm{~b}$ & 0.22 \\
\hline \multirow[t]{3}{*}{$\mathrm{S}$} & Biomass & 0.80 & 1.01 & 0.80 & 0.54 & 0.82 & 0.82 & 0.95 \\
\hline & Standing dead & 0.21 & 0.12 & 0.72 & 0.71 & 0.48 & 0.47 & 0.07 \\
\hline & Litter & 1.08 & 0.59 & $1.35 \mathrm{ab}$ & 1.19 & 0.47 & $0.31 \mathrm{~b}$ & 0.19 \\
\hline \multicolumn{9}{|l|}{$\mathrm{Mg}$} \\
\hline \multirow[t]{3}{*}{$\mathrm{R}$} & Biomass & 0.18 & 0.32 & 0.18 & 0.20 & 0.27 & 0.24 & 0.36 \\
\hline & Standing dead & 0.02 & 0.03 & 0.16 & 0.12 & 0.08 & 0.07 & 0.02 \\
\hline & Litter & 0.08 & 0.06 & $0.15 a$ & 0.13 & 0.05 & $0.08 \mathrm{a}$ & 0.04 \\
\hline \multirow[t]{3}{*}{ I } & Biomass & 0.17 & 0.26 & 0.14 & 0.11 & 0.19 & 0.29 & 0.14 \\
\hline & Standing dead & 0.02 & 0.03 & 0.12 & 0.10 & 0.05 & 0.07 & 0.01 \\
\hline & Litter & 0.04 & 0.05 & $0.09 \mathrm{~b}$ & 0.08 & 0.05 & $0.04 \mathrm{ab}$ & 0.03 \\
\hline $\mathrm{S}$ & Biomass & 0.14 & 0.23 & 0.17 & 0.13 & 0.21 & 0.18 & 0.17 \\
\hline & Standing dead & 0.03 & 0.02 & 0.12 & 0.10 & 0.06 & 0.05 & 0.01 \\
\hline & Litter & 0.07 & 0.05 & $0.11 \mathrm{ab}$ & 0.08 & 0.03 & $0.03 \mathrm{~b}$ & 0.02 \\
\hline
\end{tabular}

response in ground vegetation and that removal or incorporation of harvest residue will not result in any significant difference in understory vegetation biomass compared to when harvest residues remain on the soil surface. The smaller amount of understory biomass in treatment I at the end of first spring may be due to disturbance caused by the incorporation of harvest residues into the soil, as reported by Lister (1999) and Brosofske et al. (2001) in studies on the impact of site preparation activities.

Several studies report the negative effect of shading by harvest residues left on the soil surface on ground vegetation biomass, several years after planting or clear cutting (e.g. Fahey et al., 1991, for Sitka spruce plantations in North Wales, and Olsson and Staaf, 1995, for coniferous forests in Sweden). This trend was not observed in the present study, as treatments $\mathrm{R}$ and $\mathrm{S}$ exhibited similar amounts of understory biomass over the entire study period. Only the study of Olsson and Staaf (1995), on Swedish coniferous forests, assessed amounts of harvest residues at the beginning of the experiment (18-41 $\mathrm{t} \mathrm{ha}^{-1}$ ), which were found to be similar to amounts measured in an area close to the study site (39 $\mathrm{t} \mathrm{ha}^{-1}$ ) in a previous study (Jones et al., 1999). The study on Swedish coniferous forests was carried out at sites in a colder climate and we hypothesise that the differences encountered may 


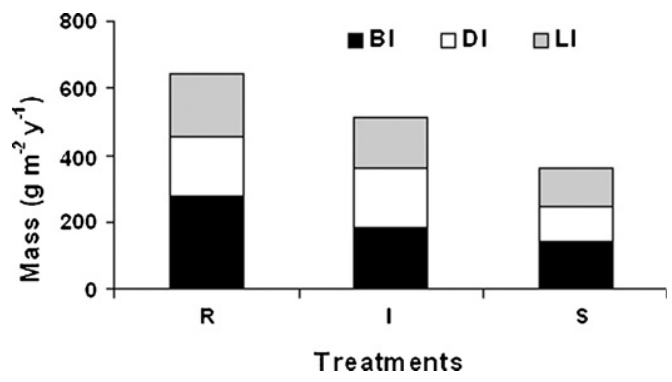

Fig. 2. Annual increase in standing biomass (BI), standing dead mass (DI) and litter (LI) $\left(\mathrm{g} \mathrm{m}^{-2}\right)$ in treatment plots between March 2006 and March 2007. Treatments are given in Table 1.

be related to the higher decomposition rate of harvest residues in coastal Mediterranean areas, as described by Berg et al. (1993) observations along a European decomposition transect. Further, the comparable understory biomass values at the beginning of the study in treatments $S$ and $R$ may be explained by the fast decomposition rate $\left(0.84\right.$ year $^{-1}$ at the end of the first year) also reported by Azevedo et al. (2004) for the foliage of eucalyptus harvest residues, at a similar site.

Understory vegetation increased in all treatments up until the third growing season (second year after planting) and then steadily decreased until the end of the study, similar to findings observed by Fabião et al. (2002) in 2-year old neighbouring planted and coppiced stands. However, Gholz and Fisher (1982) reported peaks of ground vegetation levels in a later stage of Pinus elliottii plantations in Florida. The early decrease observed in our study may be a phenomenon specific to Mediterranean conditions, where eucalyptus plantations tend to have a rapid growth rate (Pereira et al., 1996), reaching the end of the rotation cycle 10-12 years after planting. In these plantations, canopy closure occurs after 5-6 years, and the leaf area index (LAI) increases from 1.6 to 2.3, after the first 3 years (Pereira et al., 1996), reaching 2.95 years after planting (Fabião, 1986). Thus, the decrease in understory biomass appears to follow the increase in LAI, as the mass of organic layers, especially in treatment $S$, strongly decreases with time. At a similar site, Madeira et al. (2004) observed variation in the mass of organic layers including harvest residues, from $65 \mathrm{tha}^{-1}$ at the beginning of rotation to approximately $14 \mathrm{tha}^{-1}$ 5 years later. The strong competition between trees and ground vegetation for scarce nutrients and water may also be another factor for the early decrease in understory.

Our results also suggest that early tree growth was only partially affected by treatments, as tree height in treatment I was only significantly greater than in treatments R and S 18 months after planting. This difference does not appear to be due to the amounts of available nutrients as reported by Azevedo et al. (2004, 2005) for incorporated residues, since treatments $S$ and $R$ showed

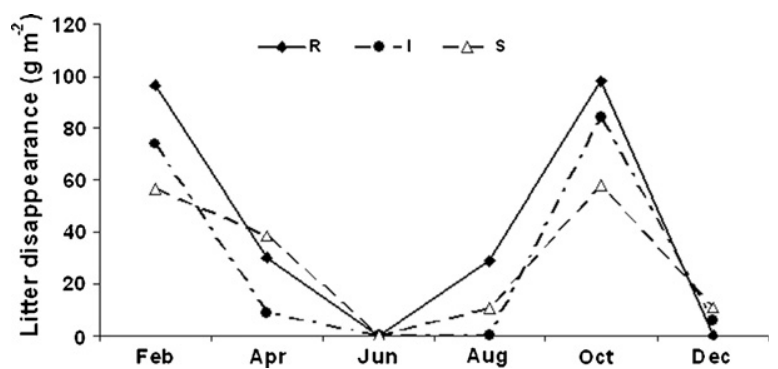

Fig. 3. Annual variation of litter disappearance $\left(\mathrm{g} \mathrm{m}^{-2}\right)$ in treatment plots between March 2006 and March 2007. Treatments are given in Table 1.

similar levels of growth. Soil disturbance in treatment I may have alleviated the effects of soil compaction, similar to findings reported by Madeira et al. (1989) for a soil preparation experiment in a eucalyptus plantation, which led to a higher tree growth rate. Soil harrowing may have improved conditions for root expansion during the early tree growth phase, resulting in more efficient uptake of water and nutrients by roots (see Fabião et al., 1990). The initial low amount of ground vegetation in treatment I (Table 2) may have also favoured tree growth through lowered competition.

Ground vegetation biomass at the end of the first and second spring after planting (0.33-1.70 and 3.20-3.52 $\mathrm{tha}^{-1}$, respectively) was much higher than expected for young trees (3- and 14-months old, respectively); in another stand close to the experimental area, the above ground biomass of 1-year old trees planted with the same spacing was only $1.9 \mathrm{tha}^{-1}$ (Madeira and Pereira, 1990). This follows a similar trend to that described by Bergquist et al. (1999) for Norway spruce and Staples et al. (1999) for white spruce (Picea glauca), both in colder climates, during the early rotation period. Nevertheless, by the end of the second year after planting, understory biomass (3.6-4.8 $\mathrm{t} \mathrm{ha}^{-1}$, Table 2) was approximately $50 \%$ of tree above ground biomass $\left(9 \mathrm{tha}^{-1}\right)$ reported in the study of Pereira et al. (1996).

Dynamics of understory NAPP between the fifth and sixth growing seasons (bimonthly sampling) suggests that treatments $\mathrm{S}$ and I may negatively affect the amounts of standing biomass, standing dead mass and litter, since treatment $\mathrm{R}$ always had the highest standing amounts of total organic mass, despite the fact that statistically significant differences between treatments were rarely observed (an effect of the high levels of variance and the low number of samples).

As expected, understory standing mass decreased substantially during the year, due to the rapid emergence of herbaceous species in spring (April-May) and their senescence by the end of the growing season (July-September). This pattern is typical of Mediterranean climatic conditions which are characterized by marked summer drought conditions and rainy mild winters, and contrasts with results reported for wetter climates (see Tremblay

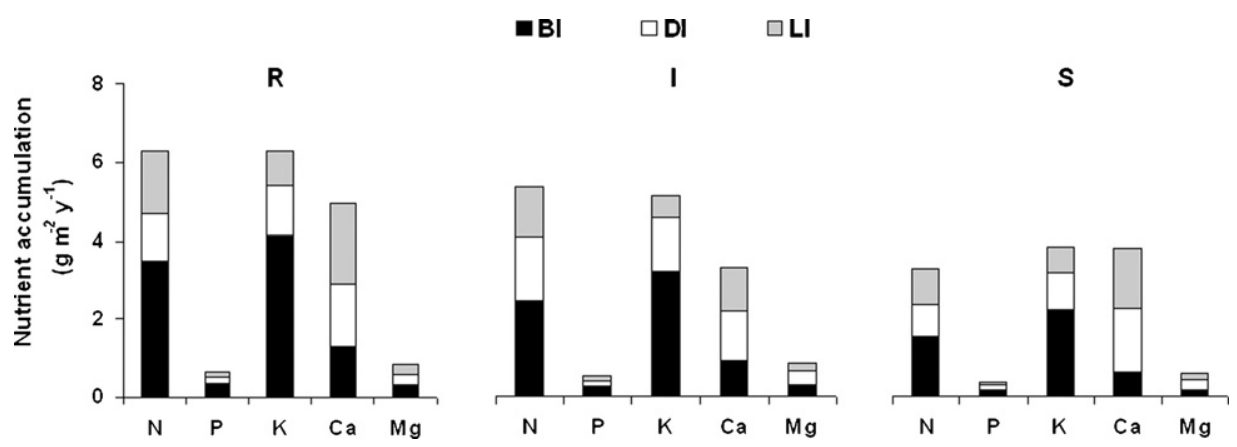

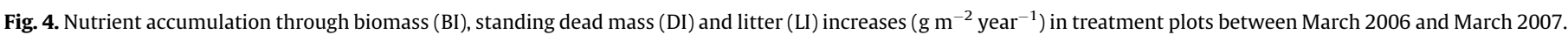
Treatments are given in Table 1. 
and Larocque, 2001 in four eastern Canadian forest types), where understory standing organic mass tends to remain relatively constant throughout the growing season.

The NAPP estimated in the present study (3.8-6.3 $\mathrm{t} \mathrm{ha}^{-1}$ year $^{-1}$ ) represents a significant proportion (approximately $30-40 \%$ ) of above ground tree production at the same rotation stage. Tree NAPP in a 4-year old eucalyptus plantation in the same area and with a similar yield class was estimated at $16.2 \mathrm{tha}^{-1}$ year $^{-1}$ (14.6 t ha year $^{-1}$ of current tree biomass increment plus $1.6 \mathrm{tha}^{-1}$ year $^{-1}$ of tree litter fall, not accounting for understory vegetation; Fabião, 1986). In 4-year old neighbouring plantation, Madeira et al. (1995) determined a NAPP of $13.6 \mathrm{tha}^{-1}$ year $^{-1}$, including a litter fall of $2.3 \mathrm{t} \mathrm{ha}^{-1}$ year $^{-1}$. Thus, the understory NAPP is clearly greater than tree annual litter fall (1.6-2.3 $\mathrm{tha}^{-1}$ year $\left.^{-1}\right)$, during the middle rotation period (ca. 4-5 years after planting) of Mediterranean eucalyptus plantations. Understory litter disappearance (1.7-2.5 $\mathrm{t} \mathrm{ha}^{-1}$ year $^{-1}$ ) suggests rapid fragmentation and decomposition, resulting in a high organic matter turnover, similar to the high annual decomposition rate of decomposing ground vegetation residues $\left(k=-1.0\right.$ year $\left.^{-1}\right)$ reported by Sá et al. (2004), in comparable environmental conditions.

The large amounts of ground vegetation biomass resulted in considerable nutrient accumulation, which was greatest in treatments $\mathrm{R}$ and $\mathrm{I}$ in the third growing season, 2 years after planting (for $\mathrm{N}, \mathrm{P}$ and $\mathrm{K}$ ) and at an earlier stage for $\mathrm{P}$ and $\mathrm{K}$ in treatment $\mathrm{S}$ in 2005 (Table 3 ). At the end of the second spring after planting, $\mathrm{N}$ and $\mathrm{K}$ levels reached $29-42$ and $36-50 \mathrm{~kg} \mathrm{ha}^{-1}$, respectively; in the third spring, $\mathrm{N}$ and $\mathrm{K}$ levels were 29-52 and $31-56 \mathrm{~kg} \mathrm{ha}^{-1}$, respectively. Thus, at the end of the second spring (14-month old trees), nutrient accumulation via ground vegetation may have been greater or of the same magnitude than that in tree above ground biomass: Madeira and Pereira (1990) observed an accumulation of $18 \mathrm{~kg} \mathrm{~N} \mathrm{ha}^{-1}$ in 1-year old trees while 2-year old trees accumulated $62 \mathrm{~kg} \mathrm{~N}^{-1}$.

Our results show that ground vegetation also plays a crucial role in nutrient retention during the early phase of tree growth in eucalyptus plantations in Mediterranean areas. The importance of ground vegetation on nutrient retention has also been reported in a lysimetric study by Emmett et al. (1991) and in a young Pinus radiata plantation under different climate conditions by Smethurst and Nambiar (1989). This is supported by findings by Azevedo et al. (2004, 2005), who showed that the amount of $\mathrm{N}$ delivered to the soil via harvest residue decomposition after 2 years, in a similar experimental site was 67 and $100 \mathrm{~kg} \mathrm{~N} \mathrm{ha}^{-1}$ and 7.3 and $7.7 \mathrm{~kg} \mathrm{P} \mathrm{ha}^{-1}$ in treatments $\mathrm{S}$ and I, respectively. During the first year, 39 and $83 \mathrm{~kg} \mathrm{ha}^{-1}$ of $\mathrm{N}$ and 122 and $126 \mathrm{~kg} \mathrm{ha}^{-1}$ of $\mathrm{K}$ were released; for $\mathrm{P}$, the values were 2.3 and $1.9 \mathrm{~kg} \mathrm{ha}^{-1}$. The amount of soil mineral $\mathrm{N}$ produced during the first year after planting was estimated to be 67 and $58 \mathrm{~kg} \mathrm{ha}^{-1}$ in treatments $\mathrm{S}$ and $\mathrm{I}$, respectively (Azevedo, 2000), while the estimated uptake by trees was only $40 \mathrm{~kg} \mathrm{ha}^{-1}$ in both treatments. In these circumstances, understory vegetation is vital to the retention of mineral $\mathrm{N}$ that is surplus to tree uptake requirements. This finding is in agreement with those of Olsson and Falkengren-Grerup (2003), who found that the presence of an understory layer considerably reduces nitrate leaching during spring. Further, Hangs et al. (2003) reported that early successional understory plant species have absorbed available nutrients more efficiently from the soil than tree seedlings.

At a rotation stage close to that of the present study (4-5 years), Madeira et al. (1995) estimated a return of $\mathrm{N}$ to the soil via tree litter fall of $15-25 \mathrm{~kg} \mathrm{~N} \mathrm{ha}^{-1}$ year $^{-1}$, a lower value than that derived for understory vegetation in this study (32-63 $\mathrm{kg} \mathrm{N} \mathrm{ha}^{-1}$ year $^{-1}$ ). This suggests that the understory strongly influences the return of nutrients to the soil at a rotation stage close to canopy closure. Given the rapid decomposition rate of ground vegetation residues, nutrients will show a high turnover rate. Results reported by Sá et al. (2004), in similar environmental conditions gave proportions of nutrients released from residues after 180 days as $50 \%, 60 \%, 90 \%$, $50 \%$ and $60 \%$ of N, P, K, Ca and Mg initial contents, respectively. These findings concur with Birk (1979), who reported a high turnover rate and emphasised the importance of understory litter in the return of nutrient elements to the soil in Australian eucalyptus forests.

The present study reinforces the unquestionable importance of understory vegetation in nutrient cycling in eucalyptus fast growing plantations in a Mediterranean environment. However, further research is necessary to determine the long term consequences of understory vegetation on nutrient dynamics at the ecosystem level.

\section{Conclusions}

This study found that early in the rotation period, differences related to harvest residue management options on eucalyptus tree growth and understory biomass were negligible. Although understory biomass was initially inhibited by soil disturbance, short term biomass amounts were of the same magnitude in the other two treatment types. Our results suggest that carbon and nutrient accumulation via the understory is unaffected by harvest residue management system, and that the understory vegetation contributes to the retention of nutrients released via decomposing residues and stimulated mineralization as a result of residue removal. In Mediterranean environments, understory vegetation plays a stronger role in nutrient accumulation than young tree above ground biomass during the initial stage of intensive eucalyptus plantations. Although close to mid-rotation period the NAPP of ground vegetation is smaller than tree biomass increment, it can play an important role in nutrient fluxes to the soil. Further research should clarify the implications of harvest residue management and understory vegetation in timber production, system sustainability and understory species richness over longer periods. Greater knowledge concerning the short and long term contribution of understory vegetation to carbon and nutrient cycling is necessary to guideline development aiming sustainable management of intensive eucalyptus plantations in Mediterranean conditions.

\section{Acknowledgements}

Funding for this study was provided by Fundação para a Ciência e a Tecnologia (FCT), Portugal (Project POCTI/42985/AGG/2001 and the first author's doctoral scholarship funding (SFRH/BD/14366/ 2003). The Störa Enso (CELBI) Pulp Company is gratefully acknowledged for allowing the use of one of its eucalyptus plantations and for helpful assistance in field work. The authors also thank the staff of Soil Laboratory of the Environmental Sciences Department for nutrient analyses and Dr. Samantha Jane Hughes for English revision of the text. Two anonymous reviewers are gratefully acknowledged for their comments and suggestions on a previous version of the manuscript.

\section{References}

Abbott, D.T., Crossley Jr., D.A., 1982. Woody litter decomposition following clearcutting. Ecology 63, 35-42.

Aber, J.D., Melillo, J.M., 1982. Nitrogen immobilization in decaying hardwood leaf litter as a function of initial nitrogen and lignin content. Can. J. Bot. 60 (11), 2263-2269.

Adams, M.A., Attiwill, P.M., 1986. Nutrient cycling and nitrogen mineralisation in eucalypt forests of southeastern Australia. II. Indices of nitrogen mineralization. Plant Soil 92, 341-362. 
Archer, J.K., 2003. Understory Vegetation and Soil Response to Silvicultural Activity in a Southeastern Mixed Pine Forest: a Chronosequence Study. Master Thesis. University of Florida, Gainesville.

Azevedo, A., 2000. Estudo da Dinâmica do Azoto e do Carbono em Plantações Florestais Intensivas. PhD Thesis. Technical University of Lisbon - Institute of Agricultural Sciences, Lisbon.

Azevedo, A., Madeira, M., Hilário, L., Marques, P., 2004. Fertilidade dos solos afectados por práticas de silvicultura. 1. Efeitos da gestão dos resíduos de abate e da sua composição química nas dinâmicas do $\mathrm{C}$ e do N. Revista de Ciências Agrárias 27 (1), 329-346.

Azevedo, A., Madeira, M., Hilário, L., Marques, P., 2005. Fertilidade dos solos afectados por práticas de silvicultura. 2. Efeitos da gestão dos resíduos de abate e da sua composição química nas dinâmicas do P, Ca, Mg e K. Revista de Ciências Agrárias 28 (2), 99-112.

Bauhus, J., Aubin, I., Messier, C., Connell, M., 2001. Composition, structure, light attenuation and nutrient content of understory vegetation in a Eucalyptus sieberi regrowth stand 6 years after thinning and fertilisation. Forest Ecol. Manage. 144, 275-286.

Berg, B., Berg, M., Bottner, P., Box, P., Breymeyer, A., Calvo de Anta, R., Couteaux, M., Gallardo, A., Escudoro, A., Kratz, W., Madeira, M., Mälkönen, E., Meentemeyer, V., Munõz, F., Piussi, P., Remacle, J., Virzo de Santo, A., 1993. Litter mass loss in pine forests of Europe and Eastern United States as compared to actual evapotranspiration on a European scale. Biogeochemistry 20, 127153.

Bergquist, J., Örlander, G., Nilsson, U., 1999. Deer browsing and slash removal affect field vegetation on south Swedish clearcuts. Forest Ecol. Manage. 115, $171-182$.

Birk, E.M., 1979. Overstorey and understorey litter fall in a eucalypt forest: spatial and temporal variability. Aust. J. Bot. 27 (2), 145-156.

Brosofske, K.D., Chen, J., Crow, T.R., 2001. Understory vegetation and site factors: implications for a managed Wisconsin landscape. Forest Ecol. Manage. 146, 75-87.

Burger, J.A., Prichett, W.L., 1984. Effects of clearfelling and site preparation on nitrogen mineralization in a southern pine stand. Soil Sci. Soc. Am. J. 48, 14321437.

Cabral, F.C., Telles, G.R., 1960. A Árvore. Ministério das Obras Públicas, Lisboa.

Carneiro, M., Fabião, A., Martins, M.C., Cerveira, C., Santos, C., Nogueira, C., Lousã, M., Hilário, L., Fabião, André, Abrantes, M., Madeira, M., 2007. Species richness and biomass of understory vegetation in a Eucalyptus globulus Labill. coppice as affected by slash management. Eur. J. Forest Res. 126, 475-480.

Carneiro, M., Fabião, A., Martins, M.C., Fabião, André, Abrantes da Silva, M., Hilário, L., Lousã, M., Madeira, M., 2008. Effects of harrowing and fertilisation on understory vegetation and timber production of a Eucalyptus globulus Labill. Plantation in Central Portugal. Forest Ecol. Manage. 255, 591597.

Carnus, J.M., Parrotta, J., Brockerhoff, E.G., Arbez, M., Jactel, H., Kremer, A., Lamb, D., O'Hara, K., Walters, B., 2003. Planted Forests and Biodiversity. In: UNFF Intersessional Experts Meeting on the Role of Planted Forests in Sustainable Forest Management, New Zealand.

Costa, J.C., Capelo, J., Lousã, M., Espírito-Santo, M.D., 2002. Os sobreirais do Divisório Português: Asparago aphylli - Quercetum suberis. Quercetea 3, 81-98.

Cowie, A.L., Smith, P., Johnson, D., 2006. Does soil carbon loss in biomass production systems negate the greenhouse benefits of bioenergy? Mitigat. Adapt. Strat. Global Change 11, 979-1002.

Crowe, S., 1966. Forestry in the Landscape. Forestry Commission Booklet No. 18. Her Majesty's Stationery Office, London.

Crowe, S., 1978. The Landscape of Forests and Woods. Forestry Commission Booklet No. 44. Her Majesty's Stationery Office, London.

Emmett, B.A., Anderson, J.M., Hornung, M., 1991. Nitrogen sinks following two intensities of harvesting in a Sitka spruce forest (N, Wales) and the effect of establishment of the next crop. Forest Ecol. Manage. 41, 81-93.

Fabião, A.M.D., 1986. Contribuição para o Estudo da Dinâmica da Biomassa e da Produtividade Primária Líquida em Eucaliptais. Região Litoral do Centro de Portugal. PhD Thesis. Technical University of Lisbon - Institute of Agricultural Sciences, Lisbon.

Fabião, A., Madeira, M., Steen, E., 1990. Effect of water and nutrient supply on root distribution in a Eucalyptus globulus plantation. Water Air Soil Pollut. 54, 635640.

Fabião, A., Martins, M.C., Cerveira, C., Santos, C., Lousã, M., Madeira, M., Correia, A., 2002. Influence of soil and organic residue management on biomass and biodiversity of understory vegetation in a Eucalyptus globulus Labill. plantation. Forest Ecol. Manage. 171, 87-100.

Fahey, T.J., Hill, M.O., Stevens, P.A., Hornung, M., Rowland, P., 1991. Nutrient accumulation in vegetation following conventional and whole-tree harvest of Sitka spruce plantations in North Wales. Forestry 64, 271-288.

Forestry Commission, 1994. Forest Landscape Design Guidelines. Her Majesty's Stationery Office, London.

Gholz, H.L., Fisher, R.F., 1982. Organic matter production and distribution in slash pine (Pinus elliottii) plantations. Ecology 63, 1827-1839.

Gholz, H.L., Hawk, G.M., Campbell, A., Cromack Jr., K., Brown, A.T., 1985. Early vegetation recovery and element cycles on a clear-cut watershed in western Oregon. Can. J. Forest Res. 15, 400-409.

Halpern, C.B., Spies, T.A., 1995. Plant species diversity in natural and managed forests of the Pacific Northwest. Ecol. Appl. 5, 913-934.
Hangs, R.D., Knight, J.D., Van Rees, K.C.J., 2003. Nitrogen uptake characteristics for roots of conifer seedlings and common boreal forest competitor species. Can. J. Forest Res. 33, 156-163.

Hartley, M.J., 2002. Rationale and methods for conserving biodiversity in plantation forests. Forest Ecol. Manage. 155, 81-95.

Jones, H.E., Madeira, M., Herraez, L., Dighton, J., Fabião, A., González-Rio, F. Fernandez-Marcos, M., Gomez, C., Tomé, M., Feith, H., Magalhães, M.C., Howson, G., 1999. The effect of organic matter management on the productivity of Eucalyptus globulus stands in Spain and Portugal: tree growth and harvest residue decomposition in relation to site and treatment. Forest Ecol. Manage. 122, 73-86.

Kent, M., Coker, P., 1992. Vegetation Description and Analysis. A Practical Approach. Belhaven Press, London.

Lister, T.W., 1999. Forest harvesting disturbance and site preparation effects on soil processes and vegetation in a young pine plantation. Master of Science in Forestry Thesis. Faculty of Virginia Polytechnic Institute and State University.

Madeira, M., Pereira, J.S., 1990. Productivity, nutrient immobilization and soil chemical properties in a Eucalyptus globulus plantation under different irrigation and fertilization regimes. Water Air Soil Pollut. 54, 621-634.

Madeira, M., Araújo, M.C., Pereira, J.S., 1995. Effects of water and nutrient supply on amount and on nutrient concentration of litterfall and forest floor litter in Eucalyptus globulus plantations. Plant Soil 168-169, 287-295.

Madeira, M., Melo, G., Alexandre, C., Steen, E., 1989. Effects of deep ploughing and superficial disc harrowing on physical and chemical soil properties and biomass in a new plantation of Eucalyptus globulus. Soil Till. Res. 14, 163-175.

Madeira, M., Magalhães, M.C., Azevedo, A., Fabião, A., Araújo, M.C., Pina, J.P., 2004 Efeito da gestão dos resíduos de abate nas características do solo e no crescimento de uma plantação de Eucalyptus globulus, em talhadia. Revista de Ciências Agrárias 27 (1), 414-431.

Mathers, N.J., Mendham, D.S., O'Connell, A.M., 2003. How residue management impact soil organic matter composition and quality under Eucalyptus globulus plantations in southwestern Australia? Forest Ecol. Manage. 179, 253 267.

Nyland, R.D., 1996. Silviculture, Concepts and Applications. Forestry Series. McGraw-Hill International Editions, New York.

Nyland, R.D., Leaf, A.L., Bickelhaut, D.H., 1979. Litter removal impairs growth of direct seeded Norway spruce. Forest Sci. 25, 244-246.

Olsson, B.A., Staaf, H., 1995. Influence of harvesting intensity of logging residues on ground vegetation in coniferous forests. J. Appl. Ecol. 32, 640-654.

Olsson, M.O., Falkengren-Grerup, U., 2003. Partitioning of nutrient uptake between trees and understory in oak forests. Forest Ecol. Manage. 179, 311-320.

Palviainen, M., 2005. Logging residues and ground vegetation in nutrient dynamics of a clear-cut boreal forest. Academic dissertation. The Finnish Society of Forest Science, Finnish Forest Research Institute, Faculty of Agriculture and Forestry of the University of Helsinki and Faculty of Forestry of the University of Joensuu.

Pereira, J.S., Tomé, M., Madeira, M., Oliveira, A.C., Tomé, J., Almeida, M.H., 1996. Eucalypt plantations in Portugal. In: Atiwill, P.M., Adams, M.A. (Eds.), Nutrition of Eucalypts. CSIRO Publishing, Collingwood, pp. 371-386.

Petterson, R., 1987. Primary production in arable crops: above-ground growth dynamics, net production and nitrogen uptake. Dissertation 31, Department of Ecology and Environmental Research, SLU, Uppsala.

Póvoas, I., Barral, M.F., 1992. Métodos de análises de solos. Comunicações 10. Instituto de Investigação Cientifica Tropical - Série de Ciências Agrárias. Ministério do Planeamento e da Administração do Território, Secretaria de Estado da Ciência e Tecnologia. Lisboa.

Reis, R.M., Gonçalves, M.Z., 1981. Caracterização Climática da Região Agrícola do Ribatejo e Oeste. O Clima de Portugal. Fasc. XXXII. Instituto Nacional de Meteorologia e Geofísica, Lisboa.

Sá, C., Madeira, M., Gazarini, L., 2004. Decomposição e libertação de nutrientes da necromassa de comunidades herbáceas. Revista de Ciências Agrárias XXVII (1) 457-469.

Shammas, K., O'Connell, A.M., Grove, T.S., McMurtrie, R., Damon, P., Rance, S.J., 2003. Contribution of decomposing harvest residues to nutrient cycling in a second rotation Eucalyptus globulus plantation in south-western Australia. Biol. Fertil. Soils 38, 228-235.

Smethurst, P.J., Nambiar, E.K.S., 1989. Role of weeds in the management of nitrogen in a young Pinus radiata plantation. New Forest 3, 203-224.

Smith, D.M., Larson, B.C., Kelty, M.J., Ashton, P.M.S., 1997. The Practice of Silviculture: Applied Forest Ecology, 9th ed. John Wiley \& Sons, New York.

Staples, T.E., Van Rees, K.C.J., Van Kessel, C., 1999. Nitrogen competition using 15N between early successional plants and planted white spruce seedlings. Can. J. Forest Res. 29, 1282-1289.

Stupak, I., Asikainen, A., Jonsell, M., Karltun, E., Lunnan, A., Mizaraité, D., Pasanen, K., Pärn, H., Raulund-Rasmussen, K., Röser, D., Schroeder, M., Varnagiryté, I., Vilkriste, L., Callesen, I., Clarke, N., Gaitnieks, T., Ingerslev, M., Mandre, M., Ozolincius, R., Saarsalmi, A., Armolaitis, K., Helmisaari, H.-S., Indriksons, A., Kairiukstis, L., Katzensteiner, K., Kukkola, M., Ots, K., Ravn, H.P., Tamminen, P., 2007. Sustainable utilisation of forest biomass for energy-possibilities and problems: Policy, legislation, certification, and recommendations and guidelines in the Nordic, Baltic, and other European countries. Biomass Bioenerg. 31, 666-684

Tisdall, J.M., Oades, J.M., 1982. Organic matter and water stable aggregates in soils. J. Soil Sci. 33, 141-163. 
Tremblay, N.O., Larocque, G.R., 2001. Seasonal dynamics of understory vegetation in four eastern Canadian forest types. Int. J. Plant Sci. 162 (2), 271-286.

WRB, 2006. World Reference Base for Soil Resources. 2nd ed. World Soil Resources Reports No. 103. FAO, Rome.

Yarie, J., 1980. The role of understory vegetation in the nutrient cycle of forested ecosystems in the mountain hemlock biogeoclimatic zone. Ecology 61,1498-1514.
Zbyszewski, G., Almeida F.M., 1960. Carta Geológica de Portugal (Esc. 1:50 000). Notícia Explicativa da Folha 26-D. Serviços Geológicos de Portugal, Lisboa.

Zbyzewski, G., Medeiros, A.C., Ferreira, O.V., 1966. Carta Geológica de Portugal. Notícia Explicativa da Folha 30B - Bombarral. Serviços Geológicos de Portugal, Lisboa. 